Roman. Saint-Paul, France. no. I, January I951. Bimonthly. Fr. I 200.

Securities in Motion. Data Digests, 74 Broad St. New York 4. v. I, no.I, April I95I. Monthly. $\$ 8.50$.

The Shakespeare Newsletter. 749 Franklin D. Roosevelt Drive, New York 9. v.I, no.I, March I95I. Monthly (September-June). \$I.oo.

Ships \& Sailing. Kalmbach Publishing Company, I027 North 7 th St., Milwaukee 3. v.I, no.I, June I95I. North 7th St., Milwaukee 3. v.I, no.I, June I95I. Monthly. \$5.00.

Sicilia America Illustrazione. Via Maqueda $256, \mathrm{~Pa}-$ lermo. v.I, no.I. January I95I. Monthly. Li 0.000 .
Lo Spettacolo. Via Valadier 37, Roma. v.I, no.I, January/March I95I. Frequency not given. \$5.00. Swiss Review of World Affairs. University of Chicago Press, 5750 Ellis Ave., Chicago 37. v. I, no.I, Jan-
Pats uary I95I. Monthly. \$7.00.

Terre Humaine. 43 Rue de Liège, Paris 8. no.I, January I95I. Monthly. Fr. I600.

Ukrainian Academy of Arts and Sciences in the U.S Annals. v. I, no.I, Winter I951. Semiannual. \$1.00 per issue.

World Liberalism. Liberal International, 39 St. James Place, London, S.W. I. v.I, no.I, Spring I95I. Frequency not given. Membership I ss.

By M. ALLYN FOX

\title{
Friends of the Library Groups in Colleges and Universities
}

Mr. Fox is executive assistant, Brooklyn College Library.

$\mathrm{T}$

HIS ARTICLE summarizes a survey of Friends of the Library Groups in colleges and universities. The survey was part of an investigation which may result in a revised edition of previous ALA publications on Friends Groups. The manuscript is now in the hands of the Committee on Friends of Libraries.

A questionnaire was sent to the 102 groups known to exist in 1949 . Of 69 respondents, 37 had groups actively functioning, while 32 did not.

The reasons given most often are to promote interest and support and to acquire materials beyond the reach of ordinary budgets.

The most popular form of name is Friends of the ... Library. Others are Library Associates, Library Guild, Association of the Friends of . . Library, Association of Patrons and Friends of ... Library and Society for the Libraries.

The outline which follows provides an idea of the variety of officers in 30 groups. Titles were furnished by the respondents.
Personal contacts and direct mail are used equally to secure new members. Personal solicitation, suggestions by present members and word-of-mouth advertising are included in the former category. Direct mail consists of letters, invitations to events and various types of brochures.

The number of members ranges from about 25 to 399. All sorts of occupations are represented. A third of the groups accept students for membership. More than half of the groups do not accept business firms as members, but do accept clubs and societies.

About half of the groups are dissatisfied with their rate of growth, stating that too little time is available for promotional purposes.

The prime mover behind the organization of the groups is the librarian. Faculty, alumni and administrative officers are next in importance as organizers. Of 32 groups reporting on this question, 24 replied that the librarian was an officer of their groups.

The librarian plans and arranges meetings, solicits and acknowledges gifts, solicits members and keeps records..

Slightly more than one half of the groups 
Organization of Friends Groups

\begin{tabular}{|c|c|c|}
\hline I & $\begin{array}{l}\text { Average } \\
\text { Number } \\
\text { Holding } \\
\text { Office }\end{array}$ & Titles as Provided by Respondents \\
\hline Principal Officers & $\mathrm{r}$ & President; Chairman; Honorary chairman \\
\hline Other Principal Officers & 2 & Vice president; Vice chairman; Student vice president \\
\hline $\begin{array}{l}\text { Financial and Secretarial } \\
\text { Officers }\end{array}$ & 2 & $\begin{array}{l}\text { Treasurer; Business manager; Secretary-treasurer; Cor- } \\
\text { responding-Editorial secretary; Executive secretary; Re- } \\
\text { cording secretary; Honorary secretary }\end{array}$ \\
\hline Managing Bodies & 20 & $\begin{array}{l}\text { Council members; Council; Advisory council; Members of } \\
\text { board; Executive board; Board of directors; Committee of } \\
\text { sponsors; Executive committee; Counsellors; Directors; } \\
\text { Trustees; Honorary trustees }\end{array}$ \\
\hline
\end{tabular}

raise money by means of dues. Contributions and gifts are other means of fundraising.

Of 34 respondents, 26 claim that contributions are deductible for income tax purposes, while eight do not know. This should be investigated so that it may be mentioned in group publications.

Office space, equipment, supplies and labor are provided by colleges and universities. Only one respondent reported that no help whatever was tendered.

The order of business at organizational meetings includes discussion of the need for Friends Groups, consideration of aims, the role of groups at other institutions, election of officers and the drafting of constitutions and by-laws.

Most groups hold meetings regularly once or twice a year. Up to 49 people have attended these meetings.

Business and social meetings, annual din- ners, solicitation of library materials, membership drives, lecture series and student contests comprise group activities.

Publications and direct mail are used almost equally. Publications include those issued by the groups themselves, material issued by libraries, college and alumni publications, and local newspapers. Letters, postal cards, circulars and invitations are the direct mail used.

In order of importance members donate money, interest others, give library materials, act as hosts and advise on purchases.

Benefits derived from membership, in order of importance, are : Satisfaction in aiding a worthy cause, free use of the library, bringing together people of similar interests, and helping unite the college and the community.

Of 34 respondents, 17 issue some sort of publication. This varies in size from a single sheet to a 39-page magazine.

\section{American Librarians Work on Standards}

American librarians are taking an active part in international work on documentation. Upon recommendation of its committee on library work and documentation, the American Standards Association has informed the International Organization for Standardization (ISO) that American librarians will participate in the work of technical committee ISO 46 on Documentation. A meeting was held in Rome, Italy, in September. The ASA is the United States member of the ISO. 